\title{
Faktor-Faktor Yang Mempengaruhi Prestasi Akademik : Studi Kasus Pada Mahasiswa Program Studi Akuntansi Universitas Semarang
}

Oleh:

Dian Indriana TL, Amerti Irvin Widowati, Surjawati

\begin{abstract}
Abstrak
Penelitian ini berujuan untuk meneliti mengenai faktor-faktor yang mempengaruhi prestasi akademik mahasiswa. Prestasi akademik mahasiswa diprestasi oleh dua faktor yaitu faktor internal dan faktor eksternal. Dalam penelitian ini faktor-faktor tersebut antara lain gender, jurusan sekolah, status pernikahan, bekerja, dukungan orang tua, dan keaktifan dalam organisasi.

Prestasi akademik mahasiswa diukur dengan indeks prestasi kumulatif. Sampel penelitian ini adalah 319 mahasiswa aktif S1 Akuntansi di Universitas Semarang pada tahun 2015. Responden penelitian ini berasal duduk di 7 semester yang berbeda (kecuali semester satu). Data penelitian diperoleh melalui data primer berupa kuesioner.

Hasil penelitian menunjukkan dari enam hipotesis yang diujikan hanya terdapat satu variabel yang menunjukkan responden yang sudah bekerja dan tidak bekerja memiliki perbedaan dalam prestasi akademik yang diukur dengan indeks prestasi mahasiswa. sedangkan lima variabel yang lain yaitu: gender, status pernikahan, jurusan sekolah, dukungan orang tua dan keaktifan organisasi tidak memiliki perbedaan dalam prestasi akademik mahasiswa.
\end{abstract}

Kata kunci: prestasi akademik, mahasiswa, gender, jurusan sekolah, status pernikahan, bekerja, dukungan orang tua dan keaktifan organisasi.

\section{Pendahuluan}

Pendidikan merupakan hal yang tidak bisa dipisahkan dalam kehidupan. Pendidikan tidak bisa lepas dari kehidupan manusia dari balita hingga dewasa di seluruh lapisan masyarakat. Pada era globalisasi saat ini diperlukan SDM yang berkwalitas guna menyongsong masa depan yang cerah. Pendidikan memerlukan lembaga pendidikan sebagai organisasi yang memberikan sarana formal dalam dunia pendidikan. Salah satu lembaga pendidikan anatara lain perguruan tinggi. 
Menurut UU Nomor 2 Tahun 1989, Pasal 16, ayat (1), Perguruan tinggi merupakan kelanjutan pendidikan menengah yang diselenggarakan untuk mempersiapkan peserta didik untuk menjadi anggota masyarakat yang memiliki kemampuan akademis dan profesional yang dapat menerapkan, mengembangkan dan menciptakan ilmu pengetahuan, teknologi dan kesenian. Peserta perguruan tinggi selnjutnya disebut sebagai mahasiswa.

Menurut (Saleh, 2014) pada tingkat pendidikan tinggi, mahasiswa dituntut untuk aktif dalam proses belajar mengajar melalui media yang ada, seperti perpustakaan, jurnal, maupun internet. Hampir semua tugas yang diberikan di pendidikan tinggi umumnya menuntut mahasiswa untuk mencari literatur dan mengembangkan pola pikirnya sendiri guna penyelesaian tugas secara efektif.

Lebih lanjut persyaratan akademik di pendidikan tinggi bukan sekedar mengikuti perkuliahan saja, tetapi ada ketentuan-ketentuan lain seperti presentase kkehadiran dalam perkuliahan, penyelesaian tugas-tugas, dan ikut aktif dalam kegiatan akademik lainnya (diskusi, presentasi, mengkuti ujian, kuis). Keberhasilan mahasiswa dalam bidang akademik ditandai dengan prestasi akademik yang dicapai, ditunjukkan melalui Indeks Prestasi (IP) maupun indeks Prestasi Kumulatif serta ketepatan dalam menyelesaikan studi.

Menurut Daruyani, Wilandari, \& Yasin, 2013, Baik faktor dalam diri mahasiswa (internal) maupun faktor dari luar mahasiswa (eksternal). Beberapa penelitia telah menunjukkan banyak faktor yang mempengaruhi prestasi akademik. Faktor internal antara lain : intelegensi, konsep diri dan lain sebagainya, sedangkan Fakor eksternal antara lain: keluarga, status sosial, lingkungan akademik dan lain sebagainya) (Garkaz, Banimahd, \& Esmaeili, 2011).

Penelitian ini merupakan pengembangan dari penelitian Garkaz, Banimahd, \& Esmaeili, (2011) yang meneliti mengenai prestasi akademik mahasiswa pada The Islamic Azad University. Penelitian tersebut meneliti mengenai beberapa faktor yang berpengaruh terhadap prestasi akademik mahasiswa yaitu: gender, latar belakang pendidikan, status pekerja, status pernikahan dan dukungan keluarga. Hasil penelitian tersebut menunjukkan bahwa gender, latar belakang sekolah dan status pekerja memiliki pengaruh terhadap prestasi akademik; sedangkan status pernikahan dan dukungan keluarga tidak memiliki pengaruh yang signifikan.

Pengembangan penelitian ini yaitu penambahan variabel keatifan mahasiswa dalam organisasi. Alasan pemilihan variabel tersebut didasari bahwa untuk menjadi SDM yang berkwalitas baik tidak hanya dari sisi akademik saja melainkan juga harus memiliki jiwa kepemimpinan yang kemungkinan besar dapat diperoleh mahasiswa dengan akif

Jurnal Dinamika Sosial Budaya, Volume 18, Nomor 1, Juni 2016 
berorganisasi. Tetapi disatu sisi jika mahasiswa aktif dalam suatu organisasi kemahasiswaan maka cenderung memiliki waktu yang tidak maksimal dalam belajar yang mungkin akan berakibat pada prestasi akademik mahasiswa tersebut.

\section{Tinjauan Pustaka}

\section{Faktor-faktor Yang Mempengaruhi Prestasi Akademik}

Beberapa faktor yang akan diteliti dalam penelitian ini yang diduga memiliki pengaruh terhadap prestasi akademik mahasiswa. faktor yang diuji dalam penelitian ini berupa enam faktor. Keenam faktor tersebut antara lain:

\section{Gender}

Menurut Zahroh (2008) dalam penelitiannya menemukan bahwa ada pengaruh langsung peran gender terhadap prestasi belajar siswa SMK PGRI Turen Malang dengan signifikansi sebesar 0,001 . Siswa perempuan lebih banyak yang berprestasi dari pada siswa laki-laki. Siswa perempuan cenderung memunyai kepribadian rapi dalam belajar, motivasi untuk belajar lebih tinggi, sedangkan siswa laki-laki cenderung agak malas belajar, bersikap acuh terhadap motivasi belajar. Namun, dalam hal tantangan kesuksesan akademik siswa laki-laki lebih tinggi, sedangkan perempuan lebih bersifat aktif belajar karena pengaruh kondisi setempat yang mem- bentuk agar rajin belajar.

Berdasarkan beberapa hasil penelitian, ditemukan bahwa sex role differences belum menentukan prestasi akdemik, sedangkan academic scale dapat menentukan prestasi akademik. Selanjutnya, peran aktif dalam berorganisasi turut membantu dalam meningkatkan prestasi akademik. Oleh karena itu, perlu diteliti kembali korelasi antara perbedaan peran gender tehadap prestasi akademik

Beberapa penelitian menunjukkan bahwa mahasiswa perempuan cenderung lebih kuat dalam akademik dibandingkan dengan mahasiswa laki-laki (Gracia \& Jenkins, 2003). Hasil penelitian tersebut juga didukung oleh (Garkaz, Banimahd, \& Esmaeili, 2011).

\section{Jurusan sekolah}

Jurusan sekolah merupakan program yang peserta didik lewati ketika menempuh pendidikan menengah tingkat atas, jurusan tersebut yaitu IPA dan IPS. Secara mendasar, pembelajaran IPS berkenaan dengan kehidupan manusia yang melibatkan segala tingkah laku dan kebutuhannya. IPS berkenaan dengan cara manusia memenuhi kebutuhannya, baik kebutuhan untuk memenuhi materi, budaya dan kejiwaannya. 
Selain itu memanfaatkan sumber daya yang ada dipermukaan bumi, mengatur kesejahteraan dan pemerintahannya maupun kebutuhan lainnya dalam rangka mempertahankan kehidupan masyarakat manusia. IPS mempelajari, menelaah, dan mengkaji sistem kehidupan manusia di permukaan bumi ini dalam konteks sosialnya atau manusia sebagai anggota masyarakat. Dengan pertimbnagan bahwa manusia dalam konteks sosial demikian luas, pengajaran IPS pada jenjang pendidikan harus dibatasi sesuai dengan kemampuan peserta didik tiap jenjang, sehinnga ruang lingkup pengajara IPS pada jenjang pendidikan dasar berbeda dengan jenjang pendidikan menengah dan pendidikan tinggi.

IPA sendiri berasal dari kata sains yang berarti alam. Sains menurut Suyoso (1998:23) merupakan“pengetahuan hasil kegiatan manusia yang bersifat aktif dan dinamis tiada henti - hentinya serta diperoleh melalui metode tertentu, sistematis, objektif, bermetode dan berlaku secara universal”. Menurut Abdullah (1998:18), IPA merupakan "pengetahuan teoritis yang diperoleh atau disusun dengan cara yang khas atau khusus, yaitu dengan melakukan observasi, eksperimentasi, penyimpulan, penyusunan teori, eksperimentasi, observasi dan demikian seterusnya kait mengkait antara cara yang satu dengan cara yang lain”. Dari pendapat diatas maka di simpulkan bahwa IPA merupakan pengetahuan dari hasil kegiatan manusia yang diperoleh dengan menggunakan langkah langkah ilmiah yang berupa metode ilmiah dan didapatkan dari hasil eksperimen atau opservasi yang bersifat umum sehingga akan terus di sempurnakan.

Hasil penelitian menunjukkan bahwa mahasiswa yang memiliki nilai matematika atau latar belakang ilmu scients cenderung memiliki prestasi akademik yang lebih baik dibandingkan yang tidak (Naser \& Peel, 1998). Hasil penelitian tersbut juga didukung oleh (Garkaz, Banimahd, \& Esmaeili, 2011).

\section{Status Pekerjaan}

Pada mahasiswa yang bekerja, melakukan kegiatan akademik sekaligus mencari uang bukanlah hal yang mudah, karena dapat menyebabkan tekanan atau stress yang cukup tinggi. Penelitian (Furr \& Elling, 2000) menunjukkan bahwa mahasiswa yang bekerja cenderung memiliki tingkat stress yang lebih tinggi dibandingkan dengan mahasiswa yang tidak bekerja. Jika hal tersebut terjadi terus menerus lambat laun akan mempengaruhi afeksi serta tingkah laku mahasiswa tersebut.

Salah satu yang dibutuhkan mahasiswa selain belajar dan membagi waktu antara kuliah dan bekerja adalah adanya dukungan sosial untuk mengurangi kecemasan yang dihadapinya. Sebagai mahasiswa yang sedang bekerja, mereka dapat memperoleh dukungan sosial dari 
berbagai sumber, seperti keluarga, dosen, orang tua, teman sebayanya dan lingkungan sekitar seperti masyarakat. House (Smet, 1994) menjelaskan dukungan sosial sebagai persepsi seseorang terhadap dukungan potensial yang diterima dari lingkungan, dukungan sosial tersebut mengacu pada kesenangan yang dirasakan sebagai penghargaan akan kepedulian serta pemberian bantuan dalam konteks hubungan yang akrab.

(Rudkin \& De Zoysa, 2007) menunjukkan bahwa mahasiswa yang bekerja tidak memiliki perbedaan yang signifikan dalam prestasi akademik dengan mahasiswa yang sudah bekerja. Hasil penelitian ini juga didukung oleh (Garkaz, Banimahd, \& Esmaeili, 2011).

\section{Status Pernikahan}

Setelah melakukan pernikahan seseorang memiliki status yang berbeda dengan sebelumnya. Secara otomatis tugas dan tanggungjawab mereka juga akan bertambah, jika sebelum menikah mereka hanya mempunyai tugas pokok untuk belajar, tetapi setelah menikah tugas mereka bertambah dengan tugas keluarga yang berupa hak dan kewajiban suami istri, sebagaimana telah diatur dalam Undang-Undang pernikahan. Banyaknya perubahan dan perbedaan yang akan dihadapi akan mempengaruhi proses kegiatan dalam perkuliahan sehingga akan berpengaruh juga terhadap prestasi akademik yang akan dihasilkan.

Hasil penelitian (Garkaz, Banimahd, \& Esmaeili, 2011)menunjukkan bahwa baik mahasiswa yang sudah menikah ataupun yang belum tidak memiliki perbedaan dalam prestasi akademik. Sehingga hal ini menunjukkan bahwa status pernikahan secara langsung tidak memiliki pengaruh terhadap prestasi akademik yang akan dicapai oleh mahasiswa.

\section{Dukungan Keluarga}

Keluarga merupakan lem- baga pendidikan pertama dan utama dalam masyarakat, karena dalam keluargalah manusia dilahirkan, berkembang menjadi de wasa. Bentuk dan isi serta cara-cara pendidikan di dalam keluarga akan selalu mempengaruhi tumbuh dan berkembangnya watak, budi pekerti dan kepribadian tiap manusia.

Pendidikan yang diterima dalam keluarga inilah yang akan digunakan oleh anak sebagai dasar untuk mengikuti pendidikan selanjutnya di sekolah. Faktor orang tua sangat berpengaruh ter- hadap keberhasilan anak dalam belajar. Tinggi rendahnya pendidikan orang tua, besar kecilnya penghasilan, cukup kurang perhatian dan bimbingan orang tua, rukun atau tidaknya kedua orang tua, semuanya itu turut mempengaruhi percapaian hasil belajar. Hasil penelitian (Garkaz, Banimahd, \& Esmaeili, 2011) menunjukkan bahwa dukungan keluarga tidak memiliki pengaruh yang signifikan terhadap prestasi akademik mahasiswa. sehingga hal 
tersebut menunjukkan bahwa tidak ada perbedaan antara mahasiswa yang didukung oleh keluarga maupun yang tidak.

6. Keaktifan Berorganisasi

Peran aktif berorganisasi adalah seseorang yang ikut berpartisipasi, terlibat dalam pengambilan keputusan, terlibat dalam memberikan dampak kemajuan atau produktivitas organisasi. Peran aktif berorganisasi dapat ber- bentuk loyalitas dan komitmen untuk terlibat pada kegiatan atau program organisasi.

\section{Hipotesis}

Berdasarkan penjelasan diatas maka hipotesis dalam penelitian ini antara lain:

H1. : Terdapat Perbedaan Prestasi Akademik antara mahasiswa penerempuan dengan mahasiswa perempuan.

H2. : Terdapat Perbedaan Prestasi Akademik antara mahasiswa dengan jurusan sekolah IPA dengan Jurusan Sosial

H3. : Terdapat Perbedaan Prestasi Akademik antara mahasiswa yang sudah bekerja dengan yang belum bekerja.

H.4 : Terdapat Perbedaan Prestasi Akademik antara mahasiswa yang sudah menikah dengan yang belum menikah.

H5. : Terdapat Perbedaan Prestasi Akademik antara mahasiswa yang memperoleh dukungan dari keluarga dengan yang tidak memperoleh dukungan.

H6. : Terdapat Perbedaan Prestasi Akademik antara mahasiswa yang aktif berorganisasi dengan yang tidak aktif berorganisasi.

\section{Metode Penelitian}

Sampel penelitian ini adalah 319 mahasiswa aktif S1 Akuntansi di Universitas Semarang pada tahun 2015. Responden penelitian ini berasal duduk di 7 semester yang berbeda (kecuali semester satu). Hal tersebut karena mahasiswa yang masih duduk disemester satu belum memiliki IPK. Data penelitian diperoleh melalui data primer berupa kuesioner yang dibentuk dari penelitian (Garkaz, Banimahd, \& Esmaeili, 2011).

\section{Hasil Penelitian}

Hasil penelitian ini adalah sebagai berikut: 


\begin{tabular}{|c|c|c|c|c|c|}
\hline & Rata-rata & Std. Deviation & T-Test & Degree of freedom & Sig. Level \\
\hline \multicolumn{6}{|l|}{ 1. Gender } \\
\hline wanita & 3,22 & 0,362 & $-0,33$ & 317 & 0,974 \\
\hline Laki-laki & 3,22 & 0,407 & & & \\
\hline \multicolumn{6}{|l|}{ 2. Jurusan sekolah } \\
\hline Exact & 3,21 & 0,372 & $-0,142$ & 317 & 0,887 \\
\hline Sosial & 3,22 & 0,375 & & & \\
\hline \multicolumn{6}{|l|}{ 3. Status Pernikahan } \\
\hline Sudah Menikah & 3,27 & 0,345 & 0,738 & 317 & 0,468 \\
\hline Belum Menikah & 3,21 & 0,376 & & & \\
\hline \multicolumn{6}{|l|}{ 4. Bekerja } \\
\hline Sudah Bekerja & 3,24 & 0,366 & 2,634 & 317 & 0,012 \\
\hline Tidak Bekerja & 3,05 & 0,401 & & & \\
\hline \multicolumn{6}{|l|}{ 5. Dukungan Orang Tua } \\
\hline Ada Dukungan & 3,23 & 0,376 & 1,133 & 317 & 0,266 \\
\hline Tidak Ada Dukungan & 3,14 & 0,346 & & & \\
\hline \multicolumn{6}{|l|}{ 6. Keaktifan Organisasi } \\
\hline Aktif & 3,23 & 0,394 & 0,265 & 317 & 0,792 \\
\hline Tidak Aktif & 3,22 & 0,368 & & & \\
\hline
\end{tabular}

Berdasarkan tabel diatas menunjukkan bahwa dari enam hipotesis yang diujikan hanya terdapat satu variabel yang menunjukkan responden yang sudah bekerja dan tidak bekerja memiliki perbedaan dalam prestasi akademik yang diukur dengan indeks prestasi mahasiswa. sedangkan lima variabel yang lain yaitu: gender, status pernikahan, jurusan sekolah, dukungan orang tua dan keaktifan organisasi tidak memiliki perbedaan dalam prestasi akademik mahasiswa.

\section{Prestasi Mahasiswa dan Gender}

Berdasarkan hasil output SPSS menunjukkan bahwa tidak terdapat perbedaan prestasi akademik mahasiswa antara mahasiswa laki-laki dengan mahasiswa wanita. Jika melihat ratarata perbedaan indeks prestasi mahasiswa laki-laki dengan mahasiswa wanita juga tidak memiliki perbedaan yang berarti.

Hasil penelitian ini tidak mendukung penelitian sebelumnya (Gracia \& Jenkins, 2003) dan (Garkaz, Banimahd, \& Esmaeili, 2011), yang menunjukkan bahwa gender memainkan peran penting dalam pencapaian prestasi akademik. Pada penelitian ini perolehan prestasi akademik antara mahasiswa laki-laki dan mahasiswa wanita tidak ada perbedaan.

\section{Prestasi Mahasiswa dan Status Pernikahan}

Berdasarkan output SPSS menunjukkan bahwa tidak terdapat perbedaan signifikan antara mahasiswa yang sudah menikah dan yang belum menikah. Jika dilihat dari rata-rata 
indeks prestasi mahasiswa menunjukkan bahwa indeks prestasi mahasiswa yang sudah menikah memiliki indeks prestasi yang lebih baik dibandingkan dengan yang belum menikah.

Hasil penelitian ini mendukung penelitian (Garkaz, Banimahd, \& Esmaeili, 2011) yang menunjukkan hasil yang sama dengan penelitan ini. Hal ini berarti status pernikahan bukan merupakan halangan bagi responden untuk memiliki prestasi yang baik.

\section{Prestasi mahasiswa dan Jurusan Sekolah}

Berdasarkan hasil output SPSS menunjukkan bahwa tidak terdapat perbedaan signifikan antara mahasiswa dari jurusan exact dan sosial. Tetapi jika dilihat dari rata-rata perolehan indeks prestasi kumulatif menunjukkan bahwa mahasiswa yang berasal dari jurusan sosial memiliki indeks prestasi akademik yang lebih tinggi. Hal ini disebabkan bahwa akuntansi sebagai ilmu sosial sudah responden pahami sejak dibangku sekolah, sehingga ketika responden melanjutkan dibangku kuliah tidak mengalami banyak kesulitan.

Hasil penelitian ini tidak mendudukung penelitian (Garkaz, Banimahd, \& Esmaeili, 2011) yang menunjukkan terdapat perbedaan signifikan. Selain itu mahasiswa dengan jurusan exact juga memiliki indeks prestasi kumulatif yang lebih tinggi dibandingkan lainnya.

\section{Prestasi mahasiswa dan Bekerja}

Berdasarkan output SPSS menunjukkan hasil terdapat perbedaan signifikan antara mahasiswa yang sudah bekerja dan yang tidak bekerja. Secara rata-rata perolehan indeks prestasi akademik kumulatif menunjukkan bahwa responden yang sudah bekerja memiliki indeks prestasi kumulatif yang lebih tinggi dibandingkan yang tidak bekerja.

Hasil penelitian ini mendukung penelitian (Garkaz, Banimahd, \& Esmaeili, 2011) yang menunjukkan bahwa terdapat perbedaan signifikan antara mahasiswa yang bekerja dan tidak bekerja. Tetapi berbeda dengan penelitian ini, penelitian (Garkaz, Banimahd, \& Esmaeili, 2011) menunjukkan bahwa mahasiswa yang tidak bekerja memiliki indeks prestasi akademik yang leih tinggi dibandingkan yang lainnya.

\section{Prestasi mahasiswa dan Dukungan Orang Tua}

Berdasarkan hasil output SPSS menunjukkan bahwa tidak terdapat perbedaan signifikan antara mahasiswa yang mendapat dukungan dari orang tua dengan yang tidak memperoleh dukungan dari orang tua. Tetapi jika dilihat dari rata-rata perolehan indeks prestasi kumulatif menunjukkan bahwa mahasiswa yang berasal memperoleh dukungan dari orang tua memiliki indeks prestasi akademik yang lebih tinggi. 
Hasil penelitian ini tidak mendudukung penelitian (Garkaz, Banimahd, \& Esmaeili, 2011) yang menunjukkan terdapat perbedaan signifikan. Selain itu mahasiswa dengan dukungan dari orang tua memiliki indeks prestasi kumulatif yang lebih tinggi dibandingkan lainnya.

\section{Prestasi mahasiswa dan Keaktifan Organisasi}

Berdasarkan hasil output SPSS menunjukkan bahwa tidak terdapat perbedaan signifikan antara mahasiswa yang aktif organisasi dengan yang tidak aktif organisasi. Tetapi jika dilihat dari rata-rata perolehan indeks prestasi kumulatif menunjukkan bahwa mahasiswa yang aktif organisasi memiliki indeks prestasi akademik yang lebih tinggi.

\section{Penutup}

\section{Kesimpulan}

Berdasarkan pembahasan diatas, penelitian ini menyimpulkan yaitu dari enam hipotesis yang diujikan hanya terdapat satu variabel yang menunjukkan responden yang sudah bekerja dan tidak bekerja memiliki perbedaan dalam prestasi akademik yang diukur dengan indeks prestasi mahasiswa. sedangkan lima variabel yang lain yaitu: gender, status pernikahan, jurusan sekolah, dukungan orang tua dan keaktifan organisasi tidak memiliki perbedaan dalam prestasi akademik mahasiswa.

Adapun keterbatasan dalam penelitian ini antara lain: kuesioner dalam penelitian ini tidak memberikan gambaran mengenai: tingkatan semester kuliah sehingga tidak bisa menggambarkan trend prestasi mahasiswa pada setiap angkatan. Selanjutnya jurusan pendidikan sekolah tingkat atas, hal ini dikarenakan tidak semua mahasiswa berasal dari SMA adapun beberapa diantara mahasiswa yang berasal dari SMK, sehingga pada penelitian ini dibagi menjadi exact dan sosial. Dan tidak ada pilihan untuk bidang kerja dalam pertanyaan bidang mahasiswa bekerja, hanya uraian saja. Sehingga beberapa diantaranya hanya mendeskripsikan pekerjaan yang mereka lakukan tanpa menyebutkan bidang usaha perusahaan tempat responden bekerja. Oleh karena itu pada penelitian ini bidang pekerjaan menggunakan justifikasi peneliti.

\section{Saran}

Guna memperbaiki penelitian ini, maka penelitian yang akan datang diharapkan antara lain:

1. Menambah item dalam kuesioner yaitu: tingkat semester, serta pilihan industri perusahaan responden,dan pilihan bentuk dukungan orang tua. 
2. Diharapkan pada penelitian bisa menggunakan wawancara untuk beberapa sampel, yang dapat digunakan untuk memperkuat hasil penelitian.

Daftar Pustaka

Daruyani, S., Wilandari, Y., \& Yasin, H. (2013). Faktor-Fakor Yang Mempengaruhi Indeks Prestasi Mahasiswa FSM Universitas Diponegoro Semester Pertama Dengan Metode Regresi Logistik Biner. Dalam S. Daruyani (Penyunt.), Seminar Nasional Statistika. Semarang, hal. 185 - 193. Universitas Diponegoro.

Furr, S., \& Elling, T. (2000). The Influence of Work on College Student Development. NAPSA Journal, 37, 454 - 470.

Garkaz, M., Banimahd, B., \& Esmaeili, H. (2011). Factors Affecting Students' Performance : The Case Of Students At The Islamic Azad University. International Conference on Education and Educational Psychology. 29, hal. 122 - 128. Elsevier.

Gracia, L., \& Jenkins, E. (2003). A quantitative Exploration of Student Performance on an Undergraduate Accounting Programme of Study. Accounting Student, 12(1), 15 - 32.

Naser, K., \& Peel, M. (1998). An Exploratory Study The Impact of Intervening Variables on Student Performance In a Principle of Accounting Course. Accounting Education: an International Jounal, 7(3), 209 - 223.

Rudkin, K., \& De Zoysa, A. (2007). Educating With Social Justice: Public Interest Vs Private Benefit. International Review of Business Research Papers, 3(2), 87 - 99.

Saleh, M. (2014). Pengaruh Motivasi, faktor Keluarga, Lingkungan Kampus dan Aktif Berorganisasi Terhadap Prestasi Akademik. PHENOMENON, 4(2), 109 - 141.

Jurnal Dinamika Sosial Budaya, Volume 18, Nomor 1, Juni 2016 